\title{
Value Discipline Dimensions on Organisational Performance and Competitive Advantage: A Study on Pharmaceutical Companies in Diabetes Care
}

\author{
Debasis Bharadwaj ${ }^{1}$, Ayesha Farooq ${ }^{1} \&$ Biranchi N Jena $^{2}$ \\ ${ }^{1}$ FMS, Aligarh Muslim University, Aligarh, Uttar Pradesh, India \\ ${ }^{2}$ Symbiosis Institute of Health Sciences, India \\ Correspondence: Debasis Bharadwaj, Aligarh Muslim University, Aligarh, Uttar Pradesh, India. E-mail: \\ debasis15@yahoo.com
}

Received: April 18, 2017 Accepted: May 8, $2017 \quad$ Online Published: May 29, 2017

doi:10.5539/ijms.v9n3p88 URL: http://doi.org/10.5539/ijms.v9n3p88

\begin{abstract}
Purpose: Recent studies highlighted the increase of competiveness and fluctuation in pharmaceutical market share, the industry facing tremendous pressure. Hence the sector has the necessity to embrace the goal of delivering their products and services with value. Specifically, diabetes care in the pharmaceutical industry has been an important agenda for providing high quality services and products to the customers in past few decades. Therefore, the present paper critically views the impact of value discipline dimensions on organizational performance and competitive advantage of diabetes care in both developed and developing countries.
\end{abstract}

Design/ methodology/ Approach: This research involves in secondary data collection due to achieving the objectives framed. Moreover, it perceives the association between the variables is not possible, conducting interviews with respondents in both developed and developing countries are also difficult

Findings: The finding shows that there is animpact of value discipline dimensions on organizational performance and competitive advantage of diabetes care in both developed and developing countries via secondary data collection method.

Research Limitations/ Implications: This study is limited to secondary research and all the findings inferred are from the information available from secondary sources.

Practical implications: The impact of value discipline dimensionson organizational performance and competitive advantage of diabetes care is effective in the context of both developed and developing countries.

Originality/ Value: Understanding the value discipline dimensions impact on organizational performance and competitive advantage of diabetes care is anew one. Hence this paper proposes this concept in both developed and developing countries perspective.

Keywords: competitive advantage, organizational performance, value discipline dimensions, customer intimacy, developing countries, product innovation, operational effectiveness

\section{Introduction}

In this competitive environment, the strategic association to organisational competitiveness and effectiveness is based on meeting the expectations and needs of the customers. To permit organisations to do so, they should know the value orientation of their particular customer base. i.e., what will be perceived as value adding by the customers particular to their sector and service or product? (Potgieter \& Roodt, 2004). Hence, Treacy \& Wiersema (1995) have identified three value disciplines in general such as Operational excellence, Customer intimacy and Product leadership on which organisations should focus. By adopting these dimensions and functioning that enables the organisations to fulfill the value added needs to customers. Specifically, organisations including pharmaceutical companies play a dominant role in providing such appropriate value needs to their customers. Heavily, it is one of the competitive industries when compared to other sectors. It is evidenced that globally, this industry has obtained immense growth and earned the revenue at over one trillion in 2014 (2016). Especially, in developing countries like India, the pharmaceutical companies have obtained the third largest position with respect to volume and 13th position in value (2016). Regarding the market size as per 
the data of Ministry of Commerce and Industry, Indian pharmaceutical industry is expected to increase at the rate of $15 \%$ per annum in 2020 . This shows the increasing tendency of pharmaceutical industries in global perspective.

However, the industry is highly shattered with more small and medium sized players which are the result of overall lower industry wide margins and fierce price competition (Euromonitor International, 2015; MarketLine, 2016; McKinsey \& Company, 2016). This fluctuation in market size relies on acustomer base of products and services. Hence, this sector should embrace the goal of delivering their products and services with value (Porter $\&$ Teisberg, 2006). Specifically, diabetes care in the pharmaceutical industry has been an important agenda for providing high quality services and products to the customers in past few decades (Van Doorn-Klomberg, Braspenning, Wolters, Bouma, De Grauw, \& Wensing, 2014). Such quality of services and products towards the customers lead the organisation to achieve their competitive advantage and also support the firm to be performed well. According to Aghdaie et al. (2012), the competitive advantage is defined as the strategic advantage of a pharmaceutical company over its rivals in order to be more competitive in the market. In this aspect, previous research in diabetes care is very less. Therefore, the present paper critically views the impact of value discipline dimensions on organizational performance and competitive advantage of diabetes care in thepharmaceutical industry in both developed and developing countries.

In the following discussion, this paper critically reviews previous research papers with regards to relationship and impact of value discipline dimensions on organisational performance and competitive advantage in general and more specific to pharmaceutical companies. This is immediately followed by a detailed specification of research methods chosen in this paper. The results are presented and discussed in later section. The final section of the paper reveals the conclusion from findings and gives suggestions for future researchers and further ends with implications of thepaper.

Objectives of the study:

1) Theoretical study the relationship of value discipline dimensions and organisational performance

2) Understand through secondary research on all the variables impact on the developed and developing countries

3) Through secondary research understand impact of each variable on the Organisational performance

4) Through secondary research understand any relationship of value disciplines on competitive advantage

\section{Review of Empirical Studies}

\subsection{Relationship and Impact of Value Discipline Dimensionson Organisational Performance}

This section specifically focuses the impact and relationship of value discipline dimensions on organisational performance of organisations in general and specifically pharmaceutical companies. Hence this paper chooses the variables as value discipline dimensions like customer intimacy, product leadership to get an organisational performance of theorganisation. The reason for using these variables describes the strategic approach to the delivery and production of products and services.

\subsubsection{Customer Intimacy and Organisational Performance}

Customer intimacy strategy generally focuses on providing a unique range of customer services which allows the organisation for service personalisation and product customisation to meet customer needs. In many instances, companies stalked this strategy for providing good quality of products or services based on needs of customers. There are numerous researchers conducted in more specific to customer intimacy and organisational performance in both developed and developing countries.

In developed countries, studiessuch as (Wang \& Lo, 2003; Yim, Tse, \& Chan, 2008; Tuominen, Rajala, \& Möller, 2001; Habryn, Blau, Satzger, \& Kölmel, 2010; Habryn, Blau, Satzger, \& Kölmel, 2010; Brock \& Zhou, 2012) have identified the positive relationship between customer intimacy and organisational performance in different countries. However, these studies have failed to provide in-depth information on a specific strategy that the companies have adopted to interact with customers. Though, this gap has been filled byTuominen et al. (2001) wherein the previous study determined how companies made interaction with their customers. Not only customers, this study additionally viewed the relationship between employees and business partners in Finland. Their study reported that organisation made aquality performance with customers via proper commitment and good coordination, while for employees, organisations provide incentives and other benefits. This study further depicts that organisation had maintained good coordination such astransparency with customers as a strategy. In the same context, another studyalso determinedthe customer strategy used byorganisations to enhance their 
performance. Brock \& Zhou (2012) determined that customer intimacy strategy supports the performance of UK and German organisations with the help of making closeness, understand the perceptions and mutual understanding with customers and other stakeholders. Both studies of Tuominen et al. (2001) and Brock \& Zhou (2012) have failed to identify the scales applied to measure the customer intimacy level. This gap was filled in the study of Habryn et al. (2010) used a performance indicator called "Customer Intimacy Grade (CIG)" in Switzerland B2B organisations tomeasure the relationship of customers, team members, employees and the whole organisation. Habryn identified that the $\mathrm{B} 2 \mathrm{~B}$ organisations interact well with their customers and others via providing solutions to the challenges. But, the CIG scale was used to measure to customers alone, wherein the objective of the research is to measure all the people such as employees, team members, and others. It is not highlighted whether any other scale is used to measure the relationship of others. To our knowledge, little studies have highlighted the customer intimacy relationship scale to organisational performance. None of the studies have revealed the negative relationship of customers with organisational performance. This is due to the fact that organisations attempt to make the customers as happy. Organisations attempted to specify their relationship with customers as positive.

On the other hand, some studies implied the impact of customer intimacy strategy reflects in financial (Coltman, Devinney, \& Midgley, 2011; Kaplan \& Norton, 2001; Ralls \& Webb, 2009) and non-financial performance of the organisation (Papajorgji, 2015). Financial performance of organisation has been regulated positively by rearranging the infrastructure based on which the customer's perception and transparency in cost are maintained. As a result, the organization maintained their existing customers (Ralls \& Webb, 2009). While the non-financial performance of organisation was obtained through executing the proper business function in order to give quality customer services (Murby \& Gould, 2005). On the other hand, the impact of customer intimacy with organizational performance can rely oncommitment and trust (Yim, Tse, \& Chan, 2008; Canning \& Hanmer-Lloyd; Morgan \& Hunt, 1994; Ponder, Holloway, \& Hansen, 2016), information disclosure (Liang, Li, \& Turban, 2009), relationship commitment levels (Bugel, Verhoef, \& Buunk, 2011), repurchase intentions (Fernandes, Proenca, \& Ramboca, 2013; Olaru, Purchase, \& Peterson, 2008; Sedianingsih \& Prasetyo, 2016), and customer induced word-of-mouth (Villanueva, Yoo, \& Hanssens, 2008; Bijmolt et al., 2010).

Both relationship and impact of customer intimacy on theorganisationare reflected in developing countries as well. For example, the study of Wang \& Lo (2003) examined the positive relationship between customers and organisation. The positive impact was observed between the two through thequality of products, and services, value and satisfaction, and transparency of revenue. This is consistent with the findings of Yim et al. (2008) which examined how consumers create loyalty towards Chinese firms. Their study emphasised that interaction between customers and employees impacts customer's existence in theorganisation. All the above studies revealed that the positive relationship with customers enhances better organizational performance and organisations also performed well on the basis of customer's perception.

\subsubsection{Product Leadership and Organisational Performance}

Product leadership is one of the important value discipline dimensions which play a lead role in deciding the performance of theorganisation. Hence this relationship is a necessity to focus on both developed and developing countries.

The relationship of product leadership on organizational performance was viewed by various studies in three different constructs such as product innovation, product differentiation and product advantage (Mohammadi, Khan, Karami, Malekshahi, Heydari, \& Moradi, 2014; Silberzahn \& Van Dyck, 2011; Hill \& Jones, 2009) in general. Product innovation is the significant aspect in the establishment of goods or services which are novel with regards to its characteristics. Hence it is broadly accepted that all organisations must innovate nonetheless of their sector in order to survive and compete in the market. In this aspect, numerous studies in developed countries highlight the positive relationship of product innovation in achieving organisational performance (Therrien, Doloreux, \& Chamberlin, 2011; Gunday, Ulusoy, Kilic, \& Alpkan, 2011; Cho \& Pucik, 2005; Calantone, Cavusgil, \& Zhao, 2002; Roberts, 1999; Han, Kim, \& Srivastava, 1998; Geroski, Machin, \& Van Reenen, 1993; Christiansen, 2015; Bratic, 2011; Andriopoulos \& Gotsi, 2006; Nieto \& Santamaria, 2007; Vilaseca-Requena, Torrent-Sellens, \& Jimenez-Zarco, 2010). Though the studies have done in cross-sectional view due to time constraints, thelimited sample size has been used.On the other hand, two studies have shown the positive association of market-oriented culture (product leadership strategy) and organizational performance (Langerak, Hultink, \& Robben, 2004; Narver, Slater, \& MacLachlan, 2004). Those studies pointed out that superior quality of products and market-oriented culture have enhanced the higher organizational performance. It might be helpful to provide more details of which new product development activities of market culture could be converted into superior performance. This gap is filled by the study of Fang et al. (2008) which examined the 
customer participation impact in New Product Development (NPD) with respect to product advantage. Few studies by Bititci (2016) in UK and Larsson \& Kinnunen (2007) in Sweden were conducted in terms of the impact of product leadership and organizational performance. Bititci (2016) pointed out the organisational performance regarding products and services based on strategy development, while (Larsson \& Kinnunen, 2007) determined the products with respect to service quality and employee satisfaction.

Similarly, few developing countries also found the relationship. For example, Luca \& Atuahene-Gima (2007) identified a significant impact on the product innovation and performance of the organisations in China. In line with this, Henard \& Dacin (2010) also explored the product innovation and organisation performance. Both the studies investigated the effects of a corporate reputation for product innovation (RPI) and its impact on consumers. Those studies specifically highlighted the product innovation for corporate reputationregarding quality and design. They failed to focus on the product packaging and style. This gap was filled by Majeed (2011) in Pakistan have measured the product competency in terms of higher product packaging, design, quality and style and better organisational performance.However,studies with respect to India are limited.

\subsubsection{Operational Excellence and Organisational Performance}

The aim of operational excellence is to achieve efficiency and cost reduction in operations, thereby attain a high level of organisational performance. To measure this relationship, various previous studies used different constructs in both developed and developing countries where in constructs such as reliability (Blischke \& Murthy, 2000; Dale, 2003; Evans \& Dean, 2003; Prajogo \& Hong, 2008), leadership (Karamat, 2013; Yanney, 2014; Matzler, Schwarz, Deutinger, \& Harms, 2008; Ling, Simsek, Lubatkin, \& Veiga, 2008). Operational effectiveness (Delarue, Van Hootegem, Procter, \& Burridge, 2008; Sparrow \& Cooper, 2014) feelings (Van Dyne \& Pierce, 2004; Knowledge.wharton, 2007), customer orientation (Asikhia, 2010; Jeong, Kim, \& Yoon, 2014) are used. In addition, other constructs such ascompetitor orientation (Wong \& Tong, 2011; Kumar, Subramanian, \&. Strandholm, 2011) inter-functional orientation (Chin, Lo, \& Ramayah, 2013; Hussain, Shah, \& Akhtar, 2016) and social orientation (Ramayah, Samat, \& Lo, 2011) are also used.Those studies found the positive relationship of operational excellence constructs and organisational performance.However, the previous studies failed to highlight the specific relationship of stakeholders.

On the other hand, few studies found the positive impact of these constructs of operational excellence and organizational performance. Excellent communication has positively impacted the performance of the organization (Aderemi, 2003; Sannie, 2006; O’Brien, 2015; Murray, 2013). However, few studies found negative impacts also (Schlegel \& Trent, 2012). These studies failed to provide in-depth information about product failure due to communication aspect.

Streamlining the complete process of organisation with better organizational strategy has provided a positive impact on the performance of theorganisation. However, the study of Friedli et al. (2013) revealed the negative impact in poor manufacturing cost which could lead the reduction of organizational performance among Pharmaceutical companies. Nevertheless, these studies shared their thought via analysis; however, noin-depth information is related to the impact of the organization. Most of the studies delivered their information on the relationship and impact of operational excellence to organizational performance wherein the relationship is mostly neutral.

The criteria for choosing the above-mentioned research papers in this review are to prove the relationship and impact of three value discipline dimensions and organisational performance to the firms in general and more specific to pharmaceutical companies.

\subsection{Relationship and Impact of Value Dimensions and Competitive Advantage}

This section specifically focuses the impact and relationship of value discipline dimensions on thecompetitive advantage of organisations in general and specific to pharmaceutical companies. Hence this paper chooses all value discipline dimensions to get a competitive advantage in this contemporary world. These dimensions act as the major source for organisations to retain their competitive advantage.

\subsubsection{Customer Intimacy and Competitive Advantage}

This section views the relationship of customer intimacy and competitive advantage. Organisations could achieve competitive advantage through customer intimacy of proper commitment towards work, trust, closeness, mutual understanding, customer needs, value perception and timeframe. Many successful organisations in worldwide adopt proper customer intimacy strategy. In this aspect, few studies positively highlight the importance of customer intimacy towards the competitive advantage of firms in both developed and developing countries. Studies were conducted also in developed countries like the U.S. (Yim, Tse, \& Chan, 2008; Bügel, Buunk, \& 
Verhoef, 2010); Sweden Osarenkhoe (2008) and the U.K. (Osarenkhoe, 2008; Anderson, Healey, \& Locke, 2005; Gooderham, 2016), Similarly, researchers have also been conducted in developing countries like China (Li, 2009; Siebers, Zhang, \& Li, 2013) and India (Indian Institute of Technology Bombay, 2016; Kamath, 2016) on customer intimacy and competitive advantage in general not specific to pharmaceutical industry. This shows that most of the organization adopted acustomer intimacy strategy to attain the competitive advantage, however, in the case of pharmaceutical firms, there are only limited studies conducted till date. However, all the above studies witnessed positive relationship towards the chosen variables. However, they failed to highlight the scales used to measure the level of customer intimacy to competitive advantage. Moreover, those studies have differed in the quality of information provided like sampling methods chosen and sample size differences.

The impact of customer intimacy towards competitive advantage was observed in few studies. Some studies highlighted that impact of high commitment of organisation support the competitive advantage (Scarpello, 1994; Lockwood \& Sphr, 2007; Vance, 2006). Likewise, trust also made a positive impact on customers which helps the organization to move to a more competitive level (Gupta, 2008; ISB, 2016; Mitra, 2006). Similarly, closeness and value perception (Brock \& Zhou, 2012; Abosag \& Lee, 2013; Todeva \& Knoke, 2005) and customer need (Nakata \& Zhu, 2006; Noble, Sinha, \& Kumar, 2002) were also assessed. Those studies did not provide the details about what extent of customer intimacy led to achieving the competitive advantage. Instead of providing the impact level whether it is positive or negative, these studies highlight the positive relationship. Studies with respect to pharmaceutical companies in relationship and impact of customer intimacy and competitive advantage are limited.

\subsubsection{Product Leadership and Competitive Advantage}

The competitive strategy of product leadership aims to create a culture which continuously provides extraordinary products to market. Several studies in this past viewed the relationship of product leadership and competitive advantage in different companies. Product innovation, differentiation, and advantage are important variables which come under product leadership to determine the competitive advantage in both developed and developing countries. Studies conducted in developed countries such as Hunt \& Morgan (1995) determined the positive relationship between product leadership and competitive advantage in Netherland. The same relationship was examined in the study of Davey \& Sanders (2012) in the U.S and viewed the significant relationship of competitive advantage and product portfolio mix, market share growth, financial returns, and competitive positioning. Similarly, another study of Atalay et al. (2013) also showed the positive relationship of product innovation and competitive advantage (delivery dependability) in general. However, these studies do not specify the strategy of organization adopted to deliver the products to customers. While, developing countries like Vinayan et al. (2012) determined the positive relationship of product leadership and competitive advantage of using four variables such as Organisational responsiveness, Effective Supply Chain Management, Cost Leadership and Product differentiation and Innovation in Malaysia. However, the study captured only the views of managers and failed to focus on other people's view of such a relationship. The studies with respect to pharmaceutical companies in relationship and impact of product leadership and competitive advantage are limited.

\subsubsection{Operational Excellence and Competitive Advantage}

Operational excellence of the firm may enhance the competitive advantage. In this regard, several studies have shown the positive association of operational excellence and competitive advantage. For example, Barney (1991) identified the positive link between firm's resources and sustained competitive advantage. This study used four indicators namely rareness, value, substitutability, and imitability to evaluate the competitive advantage to all industries not specific to pharmaceutical industries. In line with this, Ma (2000) showed the same relationship between competitive advantage and operational excellence, however, this study only focused on the operational effectiveness of operational excellence and failed to identify the level of competitive advantage. Secondly, the study is restricted to service industry and has no relevance to the pharmaceutical industry. Furthermore, Fahy (2000) made a study based on the theory of resource-based view. This study does not use any indicators to prove the competitive level and covers a different industry. Some other studies by Lumpkin et al. (2002) and Mahdi \& Almsafir (2014) also analysed the relationship between the two variables. This study also emphasized the positive relationship. Those studies are majorly conducted in developed countries.

On the other hand, the study of Sutton (2012) revealed the impact of operational excellence towards competitive advantage through the strategy development of an organisation. However, this study found only the progress and impact of two variables and lacked anin-depth view. Moreover, a limited number of studies has been done in operational excellence towards competitive advantage. With respect to thepharmaceutical sector, the study of 
Roberts (1999) identified the relationship and impact of product innovativeness and competitive advantage in the U.S. pharmaceutical industry. Later, Powell (2003) examined three companies such as pharmaceuticals, brewing, and computers in the U.S. One recent study of Whelan (2013) identified the factors which support sustainability and gaining competitive advantage in the Irish society. However, from the reviews, it is clear that these studies showed both relationship and impact of product leadership and competitive advantage in developed countries, though not many studies were conducted in developing countries perspective.

Table 1. Summary of review articles

\begin{tabular}{llll}
\hline Objectives & Countries & $\begin{array}{l}\text { Researchers } \\
\text { and Year }\end{array}$ & Methodology \\
\hline $\begin{array}{l}\text { Customer } \\
\text { intimacy and } \\
\text { organisational } \\
\text { performance }\end{array}$ & $\begin{array}{l}\text { Developed } \\
\text { countries }\end{array}$ & $\begin{array}{l}\text { Tuominen et al. } \\
(2001)\end{array}$ & Used 139 managers of manufacturing firms \\
& $\begin{array}{l}\text { Habryn et al. } \\
(2010)\end{array}$ & $\begin{array}{l}\text { Used performance indicator "Customer } \\
\text { Intimacy Grade (CIG)" to measure the } \\
\text { relationship of customers, team members, } \\
\text { employees and the whole organisation } \\
\text { The study was conducted in UK and Germany } \\
\text { utilizing multi-method research approach. }\end{array}$ \\
& & $\begin{array}{l}\text { Brock \& Zhou } \\
(2012)\end{array}$ &
\end{tabular}

\begin{tabular}{|c|c|c|}
\hline $\begin{array}{l}\text { Developing } \\
\text { countries }\end{array}$ & $\begin{array}{l}\text { Wang \& Lo } \\
\text { (2003) }\end{array}$ & Used survey method \\
\hline
\end{tabular}

\section{Major Findings}

Companies made a positive interaction with their customers in Finland by using customer intimacy scale.

B2B organisations interact well with their customers in Switzerland was noticed.

Customer intimacy strategy supports the performance of UK and German organisations with the help of making closeness, understand the perceptions and mutual understanding with customers and other stakeholders Examined the positive relationship between customers and organisation. The positive impact was observed between the two through quality of products, and services, value and satisfaction, and transparency of revenue The studyemphasised that interaction between customers and employees impacts customer's existence in Chinese organisations.

Yim et al. Used survey method

(2008)

Product
leadership and
organisational

Developed

Cho \& Pucik

countries

(2005)

Using questionnaire method for data collection

performance

\begin{tabular}{|c|c|}
\hline $\begin{array}{l}\text { Larsson \& } \\
\text { Kinnunen, } \\
(2007)\end{array}$ & Using questionnaire method \\
\hline $\begin{array}{l}\text { Therrien et al. } \\
\text { (2011) }\end{array}$ & Using questionnaire method \\
\hline
\end{tabular}

(2011)

Gunday et al. Questionnaire method

(2011)

Mohammadi et Used survey method

al. (2014)

Bititci (2016)

Used survey method

Developing

Calantone et al. Used survey method

countries

(2010)

Luca \&

With the help of questionnaire

Atuahene-Gima

(2007)
Study observed the relationship between one another such as innovativeness, quality and growth, and profitability, market value

Identified positive impact of product leadership and organizational performance in Sweden Product innovation include novelty shows a positive impact on firms' performance in selected Canadian service industries

Positive effects of innovations on firm performance was observed in Turkey manufacturing industries

Five dimensions of supply chain innovation were determined to have significant and positive direct relationship with perceived organizational performance Identified positive impact of product leadership and organizational performance in the UK Positive relationship between the product innovation and organisation performance in Iran

Significant impact on the product innovation and performance of the organisations in China 


\begin{tabular}{|c|c|c|c|c|}
\hline & & $\begin{array}{l}\text { Henard \& Dacin } \\
(2010)\end{array}$ & Questionnaire method & $\begin{array}{l}\text { Explored the positive relationship of } \\
\text { product innovation and organisation } \\
\text { performance }\end{array}$ \\
\hline & & Majeed (2011) & Questionnaire method & $\begin{array}{l}\text { Measured positive product competency } \\
\text { in terms of higher product packaging, } \\
\text { design, quality and style and better } \\
\text { organisational performance in Pakistan. }\end{array}$ \\
\hline & & $\begin{array}{l}\text { Evans \& Dean } \\
(2003)\end{array}$ & $\begin{array}{l}\text { Used data from } 188 \text { manufacturers in across } \\
\text { industries }\end{array}$ & $\begin{array}{l}\text { Organisational performance was } \\
\text { achieved by the firm through enhancing } \\
\text { their operational excellence especially in } \\
\text { improving the new product development } \\
\text { process and customer interaction }\end{array}$ \\
\hline \multirow[t]{3}{*}{$\begin{array}{l}\text { Operational } \\
\text { excellence and } \\
\text { organisational } \\
\text { performance }\end{array}$} & \multirow[t]{2}{*}{$\begin{array}{l}\text { Developed } \\
\text { countries }\end{array}$} & $\begin{array}{l}\text { Prajogo \& Hong } \\
\text { (2008) }\end{array}$ & $\begin{array}{l}\text { Used data from } 130 \mathrm{R} \& \mathrm{D} \text { divisions of Korean } \\
\text { manufacturing firms }\end{array}$ & $\begin{array}{l}\text { Operational excellence is achieved by } \\
\text { the integration of the execution of TQM } \\
\text { practices in } R \& D \text { divisions. The } \\
\text { organisational performance is well } \\
\text { achieved. }\end{array}$ \\
\hline & & Asikhia (2010) & $\begin{array}{l}\text { Two hundred and twenty two Nigerian } \\
\text { businesses }\end{array}$ & $\begin{array}{l}\text { There was a significant relationship } \\
\text { between customer orientation and firm } \\
\text { performance }\end{array}$ \\
\hline & $\begin{array}{l}\text { Developing } \\
\text { countries }\end{array}$ & $\begin{array}{l}\text { Anderson et al. } \\
(2005) ; \\
\text { Gooderham } \\
(2016) ; \\
\text { Osarenkhoe } \\
(2009)\end{array}$ & Questionnaire method & $\begin{array}{l}\text { Showed the positive relationship } \\
\text { between customer intimacy and } \\
\text { competitive advantage in UK firms }\end{array}$ \\
\hline \multirow{4}{*}{$\begin{array}{l}\text { Customer } \\
\text { intimacy and } \\
\text { competitive } \\
\text { advantage }\end{array}$} & \multirow[t]{2}{*}{$\begin{array}{l}\text { Developed } \\
\text { countries }\end{array}$} & $\begin{array}{l}\text { Osarenkhoe } \\
(2008)\end{array}$ & Survey method & $\begin{array}{l}\text { Showed the positive relationship } \\
\text { between customer intimacy and } \\
\text { competitive advantage in Sweden }\end{array}$ \\
\hline & & $\begin{array}{l}\text { Bügel et al. } \\
\text { (2010) }\end{array}$ & Survey method & $\begin{array}{l}\text { Developed the social psychological } \\
\text { model I, e investment model. This } \\
\text { model is applicable for five different } \\
\text { sectors include health insurance, mobile } \\
\text { telecom providers, banking industry, } \\
\text { supermarkets and automotive industry. } \\
\text { This model express the complete } \\
\text { customer commitment to organisation }\end{array}$ \\
\hline & \multirow[t]{2}{*}{$\begin{array}{l}\text { Developing } \\
\text { countries }\end{array}$} & $\begin{array}{l}\mathrm{Li}(2009) \\
\text { Siebers et al. } \\
(2013)\end{array}$ & Survey method & $\begin{array}{l}\text { Determined the positive relation of } \\
\text { customer intimacy and competitive } \\
\text { advantage in China. The organization } \\
\text { used different positioning strategies to } \\
\text { made the customer interaction }\end{array}$ \\
\hline & & $\begin{array}{l}\text { Hunt \& Morgan } \\
\text { (1995) }\end{array}$ & $\begin{array}{l}\text { Survey method, data collected from } 126 \text { firms } \\
\text { in Netherland }\end{array}$ & $\begin{array}{l}\text { Determined the positive relationship } \\
\text { between product leadership and } \\
\text { competitive advantage in Netherland. }\end{array}$ \\
\hline \multirow[t]{4}{*}{$\begin{array}{l}\text { Product } \\
\text { leadership and } \\
\text { competitive } \\
\text { advantage }\end{array}$} & \multirow[t]{3}{*}{$\begin{array}{l}\text { Developed } \\
\text { countries }\end{array}$} & $\begin{array}{l}\text { Davey \& } \\
\text { Sanders (2012) }\end{array}$ & Survey method & $\begin{array}{l}\text { Viewed the significant relationship of } \\
\text { competitive advantage and product } \\
\text { portfolio mix, market share growth, } \\
\text { financial returns, and competitive } \\
\text { positioning in U.S. }\end{array}$ \\
\hline & & $\begin{array}{l}\text { Atalay et al. } \\
(2013)\end{array}$ & Questionnaire method & $\begin{array}{l}\text { Showed the positive relationship of } \\
\text { product innovation and competitive } \\
\text { advantage (delivery dependability) }\end{array}$ \\
\hline & & $\begin{array}{l}\text { Vinayan et al. } \\
(2012)\end{array}$ & Questionnaire method by using four variables & $\begin{array}{l}\text { The positive relationship of product } \\
\text { leadership and competitive advantage of } \\
\text { using four variables such as } \\
\text { Organisational responsiveness, Effective } \\
\text { Supply Chain Management, Cost } \\
\text { Leadership and Product differentiation } \\
\text { and Innovation in Malaysia. }\end{array}$ \\
\hline & $\begin{array}{l}\text { Developing } \\
\text { countries }\end{array}$ & Barney (1991) & Questionnaire method & $\begin{array}{l}\text { Identified the positive link between } \\
\text { firm's resources and sustained } \\
\text { competitive advantage by using four } \\
\text { indicators namely rareness, value, } \\
\text { substitutability, and imitability }\end{array}$ \\
\hline
\end{tabular}




\begin{tabular}{|c|c|c|c|c|}
\hline \multirow[t]{4}{*}{$\begin{array}{l}\text { Operational } \\
\text { excellence and } \\
\text { organisational } \\
\text { performance }\end{array}$} & $\begin{array}{l}\text { Developed } \\
\text { countries }\end{array}$ & $\mathrm{Ma}(2000)$ & Survey method & $\begin{array}{l}\text { Positive relationship between } \\
\text { competitive advantage and operational } \\
\text { excellence and more specific to } \\
\text { operational effectiveness }\end{array}$ \\
\hline & & $\begin{array}{l}\text { Lumpkin et al. } \\
(2002) \text {; Mahdi } \\
\text { \& Almsafir } \\
(2014)\end{array}$ & Survey method & $\begin{array}{l}\text { Identified positive relationship between } \\
\text { competitive advantage and operational } \\
\text { excellence }\end{array}$ \\
\hline & & Sutton (2012) & Survey method & $\begin{array}{l}\text { Revealed the impact of operational } \\
\text { excellence towards competitive } \\
\text { advantage through the strategy } \\
\text { development of an organisation. }\end{array}$ \\
\hline & $\begin{array}{l}\text { Developing } \\
\text { countries }\end{array}$ & $\begin{array}{l}\text { Not many } \\
\text { studies } \\
\text { available }\end{array}$ & Not many studies available & Not much studies available \\
\hline
\end{tabular}

\section{Research Methodology}

The impact and relationship of value discipline dimensions for organisational performance and competitive advantage of pharmaceutical companies were determined by using secondary research method. The main purpose of choosing this method is an attempt to reviewing the different researcher's perception towards the above mentioned objective in both developed and developing countries. In this regard, secondary data collection is a more appropriate method in comparison with primary data. Quantitative research examining and estimating the data supports estimation of theassociation between the variables; however, it requires many samples and is further expensive. Whereas qualitative research covers direct observation through interview method and it is generally time taking one. Both the methods are not appropriate to the present research. Because researcher supposed to perceive the association between the variables is not possible, conducting interviews with respondents in both developed and developing countries are also difficult. Considering this difficulty, the present study adhered to secondary data collection methodology. This method is time and resource saving with mitigated bias and increased thepossibility of understanding the problem. Different sources such as magazines, text books, peer journals and other academic databases namely Emerald, PROQUEST, Springer, EBSCO and other indexed journals are also referred to obtain the aim of the study. In this aspect, there are numerous researchers in past have applied the secondary data collection method along with primary data collection include Wang \& Lo (2003), Yim et al. (2008), Luca \& Atuahene-Gima (2007). To our knowledge, there is only less number of research have focused the research in review aspect. Hence the present research in theperception of diabetes care is a novel one. To obtain the review articles, the researcher used different keywords for searching the articles such as Operational excellence OR Customer intimacy OR Product leadership OR value discipline dimensions etc from the year of 1990-2016. Due to the reason, value discipline dimensions could be adopted by different organisations on the late 1990s, and therefore the study preferably used the research studies specifically in after 1990s.

\section{Findings and Discussion}

The criteria for choosing the above mentioned research papers in perspective of both developed and developing countries in this review are to prove the relationship of three chosen value discipline dimensions on organisational performance and competitive advantage to the firms in general and more specific to pharmaceutical industries like Diabetes care. However, in this review paper, it is observed that there is not many detailed studies have been conducted in pharmaceutical industries in more specific to diabetes.

The majority of aforementioned reviews found a significant association of value discipline dimensions such as operational excellence, customer intimacy and product leadership with organisational performance and competitive advantage in both developed and developing countries.The findings and discussion with previous studies are described here:

- Value discipline dimensions of operational excellence can support the firm to achieve the organisational performance which was evidenced in various industries in both developed and developing countries. For instance, some of the past studies have shown the positive and significant relationship between operational excellence like reliability (Blischke \& Murthy, 2000; Dale, 2003; Evans \& Dean, 2003; Prajogo \& Hong, 2008), operational effectiveness (Delarue, Van Hootegem, Procter, \& Burridge, 2008; Sparrow \& Cooper, 2014) and customer orientation (Asikhia, 2010; Jeong, Kim, \& Yoon, 2014) with organisational performance. 
Similarly, the positive impact of this dimension onorganisationsalso found in few studies (Aderemi, 2003; Sannie, 2006; O’Brien, 2015; Murray, 2013)

- While their relationship with competitive advantage also shows significant relationship in few studies include (Lumpkin, Droege, Dess, 2002; Mahdi \& Almsafir, 2014), while the impact was determined by limited studiessuch as Sutton (2012). Contrary to this, thenegative context was also observed (Chopra \& Meindl, 2004).

- The findings of second dimension like customer intimacy on organisational performance and competitive advantage also found asignificant relationship. For instance, studies showed good and significant effect on organisational performance and customer intimacy like (Wang \& Lo, 2003; Yim, Tse, \& Chan, 2008; Tuominen, Rajala, \& Möller, 2001; Habryn, Blau, Satzger, \& Kölmel, 2010; Brock \& Zhou, 2012) in developed countries; and in developing countries like (Wang \& Lo, 2003; Yim, Tse, \& Chan, 2008). Similarly, the relationship was observed in competitive advantage aspect.For example; in the U.S. (Yim, Tse, \& Chan, 2008; Bügel, Buunk, \& Verhoef, 2010); Sweden (Osarenkhoe, 2008), the U.K. (Osarenkhoe, 2008; Anderson, Healey, \& Locke, 2005; Gooderham, 2016) and India (Indian Institute of Technology Bombay, 2016; Kamath, 2016). These reviews also highlighted positive relation and impact as well such as (Brock \& Zhou, 2012; Abosag \& Lee, 2013; Todeva \& Knoke, 2005).

- Thridly, the findings of relationship and impact of product leadership and organisational performance was observed in both developed and developing countries (Therrien, Doloreux, \& Chamberlin, 2011; Gunday, Ulusoy, Kilic, \& Alpkan, 2011; Cho \& Pucik, 2005; Calantone, Cavusgil, \& Zhao, 2002; Roberts, 1999; Han, Kim, \& Srivastava, 1998; Geroski, Machin, \& Van Reenen, 1993; Christiansen, 2015; Bratic, 2011; Andriopoulos \& Gotsi, 2006; Nieto \& Santamaria, 2007; Vilaseca-Requena, Torrent-Sellens, \& Jimenez-Zarco, 2010). However, these studies have some drawbacks; this has been justified in thereview section.Accordingly,competitive advantage was also observed in developed countries by Hunt \& Morgan (1995) and Davey \& Sanders (2012) also identified the positive relationship.

The present study choose developed and developing countries perception in terms of identifying the difference in whether the pharmaceutical companies of both shows any major difference in achieving competitive advantage and organisational performance. In this view, the present study analysis shows that majority of the service industries have maintained the excellent operational, product and intimacy strategy to deal with their customers in terms of motive to enhance their organisational performance and taken their organisation as acompetitive advantage in both developed and developing countries perspective. The development of any organisation has rely on the customers who are the key aspect in attaining their goalsOn the other hand, competitive advantage and organisational performance has been achieved only by maintaining the proper strategy which was evidenced in this present research.

From the analysis, it is clear that this review paper acts as the pioneer for observing the relationship of value discipline dimensions and competitive advantage to the pharmaceutical industries. Considering the availability of review papers in terms of value discipline dimensions and competitive advantage and organisational performance, the next section derived the analysis.

\section{Conclusion}

Even though a considerable number of previous researchers showed an impact of value discipline dimensions on organisational performance and competitive advantage in the context of different sectors (Burden \& Proctor, 2000; Ma, 2004; Barney, 2007; Lin, 2003; Fahy, Farrelly, \& Quester, 2004; Cousins, 2005; Porter \& Kramer, 2006; Liao \& Hu, 2007), to our knowledge little attention has been given to pharmaceutical industry. To our best knowledge, this is the first research of investigating all the above-mentioned variables in pharmaceutical companies especially a study focused on diabetes care of both developed and developing countries. Understanding the importance of value discipline in pharmaceutical companies is essential.Hence the key purpose of this review paper is to examine the impact and relationship of value discipline dimensions in diabetes care of pharmaceutical companies in both developed and developing countries. In this aspect, this paper gives a considerable evidence to literature and will serve as good evidence for future researchers in terms of identifying the relationship and impact of value dimensions on organisational performance and competitive advantage of pharmaceutical sector specifically diabetes care. It is concluded that most of the studies pointed the positive relation and impact in terms of value discipline dimensions in diabetes care of pharmaceutical companies on competitive advantage and organisational performance. However, the study has few limitations; the present study mainly focused on pharmaceutical companies in both developed and developing countries. However, there are only limited studies focussed on pharmaceutical companies in developing countries. Hence this paper used all 
industries in analysis other than pharmaceutical. Therefore, this study suggested that future research needs to be focused on analysing the importance of relationship and impact of pharmaceutical companies more in developing countries.

\section{References}

Abosag, I., \& Lee, J. W. (2013). The formation of trust and commitment in business relationships in the Middle East: Understanding Et-Moone relationships. Int. Bus. Rev., 22(3), 602-614. https://doi.org/10.1016/j.ibusrev.2012.09.002

Aderemi, S. A. (2003). Marketing Principles and Practice. Mushin: Concept Publication Limited.

Aghdaie, S. F. A., Seidi, M., \& Riasi, A. (2012). Identifying the barriers to Iran's Saffron export by using Porter's diamond model. Int. J. Mark. Stud., 4(5), 129-138. https://doi.org/10.5539/ijms.v4n5p129

Anderson, P., Healey, G., \& Locke, M. (2005). When operational excellence meets customer intimacy.

Andriopoulos, C., \& Gotsi, M. (2006). Probing the future: Mobilising foresight in multiple-product innovation firms. Futures, 38(1), 50-66. https://doi.org/10.1016/j.futures.2005.04.003

Asikhia, O. (2010). Customer Orientation and Firm Performance among Nigerian Small and Medium Scale Businesses. Int. J. Mark. Stud., 2(1), 197-212. https://doi.org/10.5539/ijms.v2n1p197

Atalay, M., Anafarta, N., \& Sarvan, F. (2013). The Relationship between Innovation and Firm Performance: An Empirical Evidence from Turkish Automotive Supplier Industry. Procedia-Soc. Behav. Sci., 75, 226-235. https://doi.org/10.1016/j.sbspro.2013.04.026

Barney, J. (1991). Firm Resources and Sustained Competitive Advantage. J. Manage., 17(1), 99-120. https://doi.org/10.1177/014920639101700108

Barney, J. (2007). Gaining and Sustaining Competitive Advantage (3rd ed.). Upper Saddle River, NJ: Pearson Education.

Bijmolt, T. H. A. et al. (2010). Analytics for Customer Engagement. J. Serv. Res., 13(3), 341-356. https://doi.org/10.1177/1094670510375603

Bititci, U. S. (2016). Managing Business Performance: The Science and The Art. UK: John Wiley \& Sons.

Blischke, W. R., \& Murthy, D. N. P. (2000). Reliability. New York: Wiley. https://doi.org/10.1002/9781118150481

Bratic, D. (2011). Achieving a Competitive Advantage by SCM. IBIMA Bus. Rev. J., pp. 1-13. https://doi.org/10.5171/2011.957583

Brock, J. K., \& Zhou, J. Y. (2012). Customer intimacy. J. Bus. Ind. Mark., 27(5), 370-383. https://doi.org/10.1108/08858621211236043

Bügel, M. S., Buunk, A. P., \& Verhoef, P. C. (2010). A Comparison of Customer Commitment in Five Sectors Using the Psychological Investment Model. J. Relatsh. Mark., 9(1), 2-29. https://doi.org/10.1080/15332660903551883

Bugel, M. S., Verhoef, P. C., \& Buunk, A. P. (2011). Customer intimacy and commitment to relationships with firms in five different sectors: Preliminary evidence. J. Retail. Consum. Serv., 18(4), 247-258. https://doi.org/10.1016/j.jretconser.2010.11.005

Burden, R., \& Proctor, T. (2000). Creating a sustainable competitive advantage through training. Team Perform. Manag. An Int. J., 6(5/6), 90-97. https://doi.org/10.1108/13527590010348200

Calantone, R. J., Cavusgil, S. T., \& Zhao, Y. (2002). Learning orientation, firm innovation capability, and firm performance. Ind. Mark. Manag., 31(6), 515-524. https://doi.org/10.1016/S0019-8501(01)00203-6

Calantone, R. J., Harmancioglu, N., \& Droge, C. (2010). Inconclusive Innovation "Returns": A Meta-Analysis of Research on Innovation in New Product Development. J. Prod. Innov. Manag., 27(7), 1065-1081. https://doi.org/10.1111/j.1540-5885.2010.00771.x

Canning, L., \& Hanmer-Lloyd, S. (n. d.). Building Trust and Commitment in the Buyer-Seller Adaptation Process. Paper prepared for the 17th IMP Conference (pp. 1-18).

Chin, C. H., Lo, M. C., \& Ramayah, T. (2013). Market Orientation and Organizational Performance: The Moderating Role of Service Quality. SAGE Open, 3(4). https://doi.org/10.1177/2158244013512664

Cho, H. J., \& Pucik, V. (2005). Relationship between innovativeness, quality, growth, profitability, and market 
value. Strateg. Manag. J., 26(6), 555-575. https://doi.org/10.1002/smj.461

Chopra, S., \& Meindl, P. (2004). Supply Chain Management: Strategy, Planning, and Operation. New Jersey: Prentice Hall.

Christiansen, B. (2015). Handbook of Research on Global Supply Chain Management. USA: IGI Global.

Coltman, T., Devinney, T. M., \& Midgley, D. F. (2011). Customer Relationship Management and Firm Performance. Fac. Commer-Pap., 26, 205-219. https://doi.org/10.1057/jit.2010.39

Cousins, P. D. (2005). The alignment of appropriate firm and supply strategies for competitive advantage. Int. J. Oper. Prod. Manag., 25(5), 403-428. https://doi.org/10.1108/01443570510593120

Dale, B. (2003). Managing Quality (4th ed.). Oxford: Blackwell Publishers.

Davey, K. S., \& Sanders, T. J. (2012). Serial strategic innovation and sustainable competitive advantage: A longitudinal case study. J. Case Res. Bus. Econ., 4, 1-20.

De Luca, L. M., \& Atuahene-Gima, K. (2007). Market Knowledge Dimensions and Cross-Functional Collaboration: Examining the Different Routes to Product Innovation Performance. J. Mark., 71(1), 95-112. https://doi.org/10.1509/jmkg.71.1.95

Delarue, A., Van Hootegem, G., Procter, S., \& Burridge, M. (2008). Teamworking and organizational performance: A review of survey-based research. Int. J. Manag. Rev., 10(2), 127-148. https://doi.org/10.1111/j.1468-2370.2007.00227.x

Euromonitor International. (2015). Pharmaceuticals in India: ISIC 2423. Report Buyer.

Evans, J., \& Dean, J. (2003). Total quality: Management, organisation and strategy (3rd ed.). Mason: Thompson South-Wester.

Fahy, J. (2000). The resource-based view of the firm: some stumbling-blocks on the road to understanding sustainable competitive advantage. J. Eur. Ind. Train., 24(2/3/4), 94-104. https://doi.org/10.1108/03090590010321061

Fahy, J., Farrelly, F., \& Quester, P. (2004). Competitive advantage through sponsorship. Eur. J. Mark., 38(8), 1013-1030. https://doi.org/10.1108/03090560410539140

Fang, E., Palmatier, R. W., \& Evans, K. R. (2008). Influence of customer participation on creating and sharing of new product value. J. Acad. Mark. Sci., 36(3), 322-336. https://doi.org/10.1007/s11747-007-0082-9

Fernandes, T., Proenca, J., \& Ramboca, M. (2013). Evaluating the impact of customer demographical characteristics on relationship outcomes. 22nd International Business Information Management Conference.

Friedli, T., Basu, P., Bellm, D., \& Werani, J. (2013). Leading Pharmaceutical Operational Excellence: Outstanding Practices and Cases. London: Springer Science \& Business Media. https://doi.org/10.1007/978-3-642-35161-7

Geroski, P., Machin, S., \& Van Reenen, J. (1993). The Profitability of Innovating Firms. RAND J. Econ., 24(2), 198. https://doi.org/10.2307/2555757

Gooderham, S. (2016). Customer intimacy as a competitive strategy. Lexisnexis.

Gunday, G., Ulusoy, G., Kilic, K., \& Alpkan, L. (2011). Effects of innovation types on firm performance. Int. J. Prod. Econ., 133(2), 662-676. https://doi.org/10.1016/j.ijpe.2011.05.014

Gupta, R. (2008). Gaining trust and confidence of clients. Financial Planning Journal, 28-30.

Habryn, F., Blau, B., Satzger, G., \& Kölmel, B. (2010). Towards a Model for Measuring Customer Intimacy in B2B Services. Lecture Notes in Business Information Processing (pp. 1-4). Geneva, Switzerland: Springer Berlin Heidelberg. https://doi.org/10.1007/978-3-642-14319-9_1

Han, J. K., Kim, N., \& Srivastava, R. K. (1998). Market Orientation and Organizational Performance: Is Innovation a Missing Link? J. Mark., 62(4), 30. https://doi.org/10.2307/1252285

Henard, D. H., \& Dacin, P. A. (2010). Reputation for Product Innovation: Its Impact on Consumers. J. Prod. Innov. Manag., 27(3), 321-335. https://doi.org/10.1111/j.1540-5885.2010.00719.x

Hill, C., \& Jones, G. (2009). Strategic Management Theory: An Integrated Approach (9th ed.). Mason, OH: Cengage Learning. 
Hunt, S. D., \& Morgan, R. M. (1995). The comparative advantage theory of competition. J. Mark., 59, 1-15. https://doi.org/10.2307/1252069

Hussain, J., Shah, F. A., \& Akhtar, S. (2016). Market Orientation and Organizational Performance in Smalland Medium Sized Enterprises. A Conceptual approach. City Univ. Res. J., 6(1), 166-180.

India Brand Equity Foundation. (2016). Indian Pharmaceutical Industry.

Indian Institute of Technology Bombay. (2016). Strategic Leadership and Business Integration for Competitive Advantage. Mumbai, India.

ISB. (2016). "Trust can be a source of significant competitive advantage to a family business" says Adi Godrej at the ISB Family Business Conference.

Jeong, D. Y., Kim, S. M., \& Yoon, D. J. (2014). Customer Orientation and Organizational Performance: Mediating Role of CRM. Adv. Sci. Technol. Lett., 57, 35-39. https://doi.org/10.14257/astl.2014.57.09

Kamath, N. (2016). Handbook of Research on Strategic Supply Chain Management in the Retail Industry. USA: IGI Global. https://doi.org/10.4018/978-1-4666-9894-9

Kaplan, R. S., \& Norton, D. P. (2001). The Strategy-focused Organization: How Balanced Scorecard Companies Thrive in the New Business Environment. Boston, Mass: Harvard Business Press.

Karamat, A. U. (2013). Impact of Leadership on Organizational Performance.

Knowledge.wharton. (2007). Managing Emotions in the Workplace: Do Positive and Negative Attitudes Drive Performance? Knowledge.wharton.

Kumar, K., Subramanian, R., \& Strandholm, K. (2011). Market Orientation And Performance: Does Organizational Strategy Matter? J. Appl. Bus. Res., 18(1), 37-49. https://doi.org/10.19030/jabr.v18i1.2099

Langerak, F., Hultink, E. J., \& Robben, H. S. J. (2004). The Impact of Market Orientation, Product Advantage, and Launch Proficiency on New Product Performance and Organizational Performance. J. Prod. Innov. Manag., 21, 79-94. https://doi.org/10.1111/j.0737-6782.2004.00059.x

Larsson, J., \& Kinnunen, J. (2007). Performance Measurement In Nonprofits Much To Be Gained Or A Waste Of Resources?.

Li, M. (2009). The Customer Value Strategy in the Competitiveness of Companies. Int. J. Bus. Manag., 4(2), 136-141. https://doi.org/10.5539/ijbm.v4n2p136

Liang, T. P., Li, Y. W., \& Turban, E. (2009). Personalized Services Asempathic Responses: The Roleof Intimacy. PACIS 2009 Proceedings Association for Information Systems.

Liao, S. H., \& Hu, T. C. (2007). Knowledge transfer and competitive advantage on environmental uncertainty: An empirical study of the Taiwan semiconductor industry. Technovation, 27(6-7), 402-411. https://doi.org/10.1016/j.technovation.2007.02.005

Lin, B. W. (2003). Technology transfer as technological learning: a source of competitive advantage for firms with limited R\&amp; D resources. R D Manag., 33(3), 327-341. https://doi.org/10.1111/1467-9310.00301

Ling, Y., Simsek, Z., Lubatkin, M. H., \& Veiga, J. F. (2008). The impact of transformational CEOs on the performance of small- to medium-sized firms: does organizational context matter? J. Appl. Psychol., 93(4), 923-934. https://doi.org/10.1037/0021-9010.93.4.923

Lockwood, N. R., \& Sphr, G. (2007). Leveraging Employee Engagement for Competitive Advantage: HR's Strategic Role.

Lumpkin, G. T., Droege, S. B., \& Dess, G. G. (2002). E-Commerce Strategies: Achieving Sustainable Competitive Advantage and Avoiding Pitfalls. Organ. Dyn., 30(4), 325-340. https://doi.org/10.1016/S0090-2616(02)00065-7

Ma, H. (2000). Competitive Advantage And Firm Performance. Compet. Rev., 10(2), 15-32. https://doi.org/10.1108/eb046396

Ma, H. (2004). Toward global competitive advantage. Manag. Decis., 42(7), 907-924. https://doi.org/10.1108/00251740410550961

Mahdi, O. R., \& Almsafir, M. K. (2014). The Role of Strategic Leadership in Building Sustainable Competitive Advantage in the Academic Environment. Procedia-Soc. Behav. Sci., 129, 289-296. https://doi.org/10.1016/j.sbspro.2014.03.679 
Majeed, S. (2011). The Impact of Competitive Advantage on Organizational Performance. Eur. J. Bus. Manag., 3(4), 191-196.

MarketLine. (2016). Pharmaceuticals in India. Report Buyer.

Matzler, K., Schwarz, E., Deutinger, N., \& Harms, R. (2008). The Relationship between Transformational Leadership, Product Innovation and Performancein SMEs. J. Small Bus. Entrep., 21(2), 139-151. https://doi.org/10.1080/08276331.2008.10593418

McKinsey, I., \& Company. (2016). Indian pharma 2020: Propelling access and acceptance, realizing true potentia. Mckinsey.

Mitra, S. K. (2006). The Puzzle of India's Governance: Culture, Context and Comparative Theory. Abingdon: Psychology Press.

Mohammadi, M. A. D., Bin, M. N. A., Khan, A., Karami, M., Malekshahi, A., Heydari, M., \& Moradi, M. (2014). Supplychain Innovation Effect on Perceived Organizational Performance in Industrial Manufacturing. World Appl. Sci. J., 32(6), 1147-1152.

Morgan, R. M., \& Hunt, S. D. (1994). The Commitment-Trust Theory of Relationship Marketing. J. Mark., 58(3), 20. https://doi.org/10.2307/1252308

Murby, L., \& Gould, S. (2005). Effective Performance Management with the Balanced Scorecard. London.

Murray, K. (2013). The Language of Leaders: How Top CEOs Communicate to Inspire, Influence and Achieve Results. New Delhi: Kogan Page Publishers.

Nakata, C., \& Zhu, Z. (2006). Information Technology and Customer Orientation: A Study of Direct, Mediated, and Interactive Linkages. J. Mark. Manag., 22(3-4), 319-354. https://doi.org/10.1362/026725706776861208

Narver, J. C., Slater, S. F., \& MacLachlan, D. L. (2004). Responsive and Proactive Market Orientation and $\begin{array}{llllll}\text { New-Product Success. } \quad J . & \text { Prod. } & \text { Innov. }\end{array}$ https://doi.org/10.1111/j.0737-6782.2004.00086.x

Nieto, M. J., \& Santamaria, L. (2007). The importance of diverse collaborative networks for the novelty of product innovation. Technovation, 27(6-7), 367-377. https://doi.org/10.1016/j.technovation.2006.10.001

Noble, C. H., Sinha, R. K., \& Kumar, A. (2002). Market Orientation and Alternative Strategic Orientations: A Longitudinal Assessment of Performance Implications. J. Mark., 66(4), 25-39. https://doi.org/10.1509/jmkg.66.4.25.18513

O'Brien, J. (2015). Category Management in Purchasing: A Strategic Approach to Maximize Business Profitability. New Dehi: Kogan Page Publishers.

Olaru, D., Purchase, S., \& Peterson, N. (2008). From customer value to repurchase intentions and recommendations. J. Bus. Ind. Mark., 23(8), 554-565. https://doi.org/10.1108/08858620810913362

Osarenkhoe, A. (2008). What characterises the culture of a market-oriented organisation applying a customer-intimacy philosophy? J. Database Mark. Cust. Strateg. Manag., 15(3), 169-190. https://doi.org/10.1057/dbm.2008.14

Osarenkhoe, A. (2008). What characterizes the culture of a relationship-focused organization applying a customer intimacy strategy? GÄVLE, SWEDEN: University of Gävle.

Papajorgji, P. (2015). Automated Enterprise Systems for Maximizing Business Performance. Hersey, PA: IGI Global.

Ponder, N., Bugg Holloway, B., \& Hansen, J. D. (2016). The mediating effects of customers' intimacy perceptions on the trust-commitment relationship. J. Serv. Mark., 30(1), 75-87. https://doi.org/10.1108/JSM-04-2014-0117

Porter, M., \& Kramer, M. (2006). Strategy \& Society: The Link Between Competitive Advantage and Corporate Social Responsibility. Harvard Bus. Rev, 84(12), 78-93.

Porter, M., \& Teisberg, E. (2006). Redefining health care: creating value-based competition on results. Boston: Harvard Business School Press.

Potgieter, A., \& Roodt, G. (2004). Measuring A Customer Intimacy Culture In A Value Discipline Context. $J$. Hum. Resour. Manag., 2(3), 25-31. https://doi.org/10.4102/sajhrm.v2i3.49

Powell, T. C. (2003). Varieties of competitive parity. Strateg. Manag. J., 24(1), 61-86. 
https://doi.org/10.1002/smj.283

Prajogo, D. I., \& Hong, S. W. (2008). The effect of TQM on performance in R\&amp;D environments: A perspective from South Korean firms. Technovation, 28(12), 855-863. https://doi.org/10.1016/j.technovation.2008.06.001

Ralls, J. G., \& Webb, K. A. (2009). Mastering the Chaos of Mergers and Acquisitions. Houston, TX: Routledge.

Ramayah, T., Samat, N., \& Lo, M. (2011). Market orientation, service quality and organizational performance in service organizations in Malaysia. Asia-Pacific J. Bus. Adm., 3(1), 8-27. https://doi.org/10.1108/17574321111116379

Roberts, P. W. (1999). Product innovation, product-market competition and persistent profitability in the U.S. $\begin{array}{lllll}\text { pharmaceutical industry. } & \text { Strateg. }\end{array}$ https://doi.org/10.1002/(SICI)1097-0266(199907)20:7\%3C655::AID-SMJ44\%3E3.0.CO;2-P

Sannie, M. B. (2006). Business Communication and Use of English. Lagos Nigeria.: M.B.A Corporate World Investment.

Scarpello, V. (1994). New Paradigm Approaches in Strategic Human Resource Management: A Commentary. Gr. Organ. Manag., 19(2), 160-164. https://doi.org/10.1177/1059601194192003

Schlegel, G. L., \& Trent, R. J. (2012). Supply Chain Risk Management: An Emerging Discipline. India: CRC Press.

Sedianingsih, I. M., \& Prasetyo, A. (2016). Repurchase Intention between Commitment and Patient Trust. Int. J. Bus. Manag. Res., 6(2), 45-56.

Siebers, L. Q., Zhang, T., \& Li, F. (2013). Retail positioning through customer satisfaction: an alternative explanation to the resource-based view. J. Strateg. Mark., 21(7), 559-587. https://doi.org/10.1080/0965254X.2013.817478

Silberzahn, P., \& Van Dyck, W. (2011). The Balancing act of Innovation (E-boek). Belgium: Lannoo Meulenhoff.

Sparrow, P., \& Cooper, C. (2014). Organizational effectiveness, people and performance: new challenges, new research agendas. J. Organ. Eff. People Perform., 1(1), 2-13. https://doi.org/10.1108/joepp-01-2014-0004

Statista. (2016). Statistics and facts about the pharmaceutical industry worldwide. Statista.

Sutton, D. (2012). Back to basics: A practitioner's guide to operations excellence. Cincinnati, Ohio: Operations Excellence Services.

Therrien, P., Doloreux, D., \& Chamberlin, T. (2011). Innovation novelty and (commercial) performance in the service sector: A Canadian firm-level analysis. Technovation, 31(12), 655-665. https://doi.org/10.1016/j.technovation.2011.07.007

Todeva, E., \& Knoke, D. (2005). Strategic Alliances \& Models of Collaboration. Manag. Decis., 43(1), 1-22. https://doi.org/10.1108/00251740510572533

Treacy, M., \& Wiersema, F. (1995). How market leaders keep their edge. Fortune, 13(2), 52-57.

Tuominen, M., Rajala, A., \& Möller, K. (2001). Integrated model of market orientation, product innovation, and market adaptation. Proceedings of the 30th. European Marketing Academy Conference.

Van Doorn-Klomberg, A. L., Braspenning, J. C. C., Wolters, R. J., Bouma, M., De Grauw, W. J. C., \& Wensing, M. (2014). Organizational determinants of high-quality routine diabetes care. Scand. J. Prim. Health Care, 32(3), 124-131. https://doi.org/10.3109/02813432.2014.960252

Van Dyne, L., \& Pierce, J. L. (2004). Psychological ownership and feelings of possession: three field studies predicting employee attitudes and organizational citizenship behavior. J. Organ. Behav, 25(4), 439-459. https://doi.org/10.1002/job.249

Vance, R. J. (2006). Employee engagement and commitment: A guide to understanding, measuring, and increasing engagement in your organization. Alexandria, VA: The SHRM Foundation.

Vilaseca-Requena, J., Torrent-Sellens, J., \& Jimenez-Zarco, A. I. (2010). ICT use in Marketing as Innovation Succes factor. Eur. J. Innov. Manag., 10(2), 268-288. https://doi.org/10.1108/14601060710745297

Villanueva, J., Yoo, S., \& Hanssens, D. M. (2008). The Impact of Marketing-Induced Versus Word-of-Mouth Customer Acquisition on Customer Equity Growth. J. Mark. Res., 45(1), 48-59. https://doi.org/10.1509/jmkr.45.1.48 
Vinayan, G., Jayashree, S., \& Marthandan, G. (2012). Critical Success Factors of Sustainable Competitive Advantage: A Study in Malaysian Manufacturing Industries. Int. J. Bus. Manag., 7(22), 29-44. https://doi.org/10.5539/ijbm.v7n22p29

Wang, Y., \& Lo, H. P. (2003). Customer-focused performance and the dynamic model for competence building and leveraging: A resource-based view. J. Manag. Dev., 22(6), 483-526. https://doi.org/10.1108/02621710310478486

Whelan, B. B. (2013). A Framework for Sustainable, Competitive Advantage for the Irish Pharmaceutical Industry. Waterford institute of Technology.

Wong, K. S., \& Tong, C. (2011). The Mediating Effects of Customer and Competitor Orientations on New Product Success. Int. J. Bus. Manag., 6(8), 34-43. https://doi.org/10.5539/ijbm.v6n8p34

Yanney, J. P. (2014). Business Strategy and Leadership Style: Impact on Organizational Performance in the Manufacturing Sector of Ghana. Am. J. Ind. Bus. Manag., 4(12), 767-775. https://doi.org/10.4236/ajibm.2014.412083

Yim, C. K. (Bennett), Tse, D. K., \& Chan, K. W. (2008). "Strengthening Customer Loyalty Through Intimacy and Passion: Roles of Customer-Firm Affection and Customer-Staff Relationships in Services. J. Mark. Res., 45(6), 741-756. https://doi.org/10.1509/jmkr.45.6.741

\section{Copyrights}

Copyright for this article is retained by the author, with first publication rights granted to the journal.

This is an open-access article distributed under the terms and conditions of the Creative Commons Attribution license (http://creativecommons.org/licenses/by/4.0/). 